\title{
Worst Forms of Child Labour in Nigeria: An Appraisal of International and Local Legal Regimes
}

\author{
Anthony N. Nwazuoke, Chinedu A. Igwe \\ Faculty of Law, Ebonyi State University, Abakaliki, Nigeria \\ Email: nwazuoketony@yahoo.com
}

Received 13 January 2016; accepted 22 March 2016; published 25 March 2016

Copyright (C) 2016 by authors and Scientific Research Publishing Inc.

This work is licensed under the Creative Commons Attribution International License (CC BY). http://creativecommons.org/licenses/by/4.0/

\section{cC) (i) Open Access}

\begin{abstract}
Child labour is a global issue of international and local concern. It had been estimated that child labour accounted for $22 \%$ of the workforce in Asia, 32\% in Africa, $17 \%$ in Latin America, and $1 \%$ in United States, Canada, Europe and other wealthy nations ${ }^{1}$. In respect of Nigeria, it had been observed that over 15 million children aged 5 - 14 years were engaged in child labour. This work examined the meaning, causes and consequences of child labour with particular emphasis on Nigeria. It undertook a comprehensive study of international and local legal instruments against child labour. In the final analysis, the authors of this work contended that the eradication of poverty and the provision of free and compulsory primary and secondary education would contribute drastically to the reduction of child labour.
\end{abstract}

\section{Keywords}

Worst, Forms, Child, Nigeria, International

\section{Introduction}

The impact of child labour on a child varies from work to work.

International legal Instruments draw a distinction between child labour simpliciter and the more aggravated forms of child labour otherwise categorized as "The Worst Forms of Child Labour"2.

Before 2003, various enactments in Nigeria provided different age limits for the term "child”. Under the

${ }^{1}$ Child Labour Laws in the United States available at http://en.wikipedia.org/viki/chid-labour-laves-in-the-United-States p. 2. Accessed on $23^{\text {rd }}$ October, 2014.

${ }^{2}$ ILO Worst Forms of Child Labour Convention, 182 of 1999, article 3 and Minimum Age Convention, 1973 , NO 138. 
Children and Young Persons Act ${ }^{3}$ a "child" was defined as a person under the age of 14 years while a young person means any person above the age of 14 years but below 17 years. The Labour Act ${ }^{4}$ and Criminal Procedure $\mathrm{Act}^{5}$ define a child as a person below the age of 12 and 14 years respectively. Both Criminal ${ }^{6}$ and Penal Codes Act imply that a child is a person under the age of 12 years.

However, in 2003 the Child's Rights Act ${ }^{7}$ unequivocally defines a child as any person under the age of 18 years. By section 274 (1) of this Act, the provisions of the Act supersedes the provisions of other enactments relating to children. The definition of a child under the Child's Rights Act is in consonance with those in earlier international treaties namely - The Convention on the Rights of the Child and the African Charter on the Rights and Welfare of the Child ${ }^{8}$. Unlike section 277(1) of the Child's Rights Act and article 2 of the African Charter on the Rights and Welfare of the Child, article 1 of the Convention on the Rights of the Child subordinates its definition of a child to contrary definitions under the laws of its state parties. For example, where the law of a state party defines a child as a person below 16 years, that definition prevails over that in article 1 of the Convention on the Rights of a Child.

Although a child is generally defined under the aforementioned international instruments as a person below 18 years, the ILO Minimum Age Convention allows States parties by a declaration appended to their ratifications to stipulate that children who are not less than 15 years $^{9}$ and in some peculiar circumstances not less than 14 years ${ }^{10}$ may be admitted to employment within the territories.

However, the age limit for the admission of children to employment may subsequently be raised by a further declaration ${ }^{11}$. Nonetheless, article 3 (1) of the Minimum Age Convention provides that where the health, safety and the morals of children are likely to be jeopardized the minimum age for employment shall not be less than 18 years. Under article 3 (3) children who are not less than 16 years may be employed in works envisaged by article 3 (1) provided their health, safety and morals are adequately protected and they have either been specifically trained or instructed on how to handle such works.

Article 3 (1) does not however specify those works which are likely to be harmful to the health, safety and morals of children. Such works can be gleaned from article 5(3) as follows-mining and quarrying, manufacturing, construction, electricity, gas and water, sanitary services, transport, storage and communication, and plantations and other agricultural undertakings mainly producing for commercial proposes but excluding family and small-scale holdings producing for local consumption and not regularly employing hired workers. As we shall soon discuss, the Worst Forms of Child Labour Convention does not only indicate those works which are likely to be hazardous to children but also provided that state parties to it shall not allow children less than 18 years admission into such employments ${ }^{12}$.

\footnotetext{
${ }^{3}$ Cap. 485, Laws of the Federation of Nigeria, (L.F.N.), 1990; section 2.

${ }^{4}$ Cap. L1, L.F.N., 2010; section 91.

${ }^{5}$ Cap. C14, L.F.N., 2010; section 2.

${ }^{6}$ Criminal Code Cap. C38, L.F.N., 2010; section 30 and Penal Code, Cap. P3 L.F.N., 2010, section 50 respectively.

${ }^{7}$ Cap. C50, L.F.N., 2010; section 277(1).

${ }^{8}$ Convention on the Rights of the Child, article 1, adopted by the by the UN General Assembly Resolution 44/25 of 20 November, 1989 and entered into force on 2 September, 1990; African Charter on the Rights and Welfare of the Child; article 11, adopted by OAU (now AU) Assembly of Heads of States and Governments in 1990. Nigeria ratified the Convention on the Rights of the Child on 19/4/1991 and the African Charter on the Rights and Welfare of the Child on 23/7/2001. See Ladan, M.T. "The Rights of Child Domestic as Victims of Human Rights Violation and Trafficking in Nigeria.” Available at: http://www.dawodu.com/ladan3.htm,p.13. Retrieved on 15/10/2007. See also ILO Worst Forms of Child Labour Convention 182 of 1999; article II, ratified by Nigeria on $2^{\text {nd }}$ October, 2002. Available at

https://www.gogle.com/search?=Ratification+of+Worst=forms+of + Child+Labour+Convention+by=Nigeria=ut. Retrieved on $14^{\text {th }}$ November 2013; and Protocol to Prevent, Suppress and Punish Trafficking in Persons, Especially Women and Children (hereinafter referred to as "Palermol Protocol”), Supplementing the United Nations Convention Against Transnational Organized Crime 2000, article 3 (d). Nigeria ratified this Protocol on 28 June, 2000 and was domesticated as Trafficking in Persons (Prohibition) Law, Enforcement and Administration Act, Cap. T23, L.F.N. 2010; Council of Europe Convention on Action Against Trafficking in Human Beings(hereinafter referred to as "Council of Europe Convention"); article 4, opened for signature on 16 May, 2005 and entered into force on Feb. 1, 2008. Available: http://en.wikipedia.rg/wiki/council of Europe Convention on Action Against Trafficking in Human Beings. Retrieved on 23/10/2014 and Inter-American Convention on International Traffic in Minors, Mar. 18, 1994 (hereinafter referred to as "Inter-American Convention"); article 2 (a), adopted at Mexico D. F.; Mexico, on march 18, 1994, at the fifty Inter-American Specialized Conference on Private International Law (CIDIP-V). Available at: http://www/.umn.edu/humansts/instree/minortraffic1994.html. Retrieved on 13/11/2014.

${ }^{9}$ Minimum Age Convention, 1973, No 138; article 2 (3).

${ }^{10}$ Ibid., article 2 (4). This Convention permits states parties with weak economy and insufficiently developed educational facilities to initially specify the age of 14 as the minimum for the admission of children to employment.

${ }^{11}$ Minimum Age Convention 1973, No 138, article 2 (2).

${ }^{12}$ ILO Worst Forms of Child Labour Convention No 182 of 1999; articles 3 and 7 (2) (a) respectively.
} 
On the other hand, child labour means any work that deprives a child of its childhood and right to education or is detrimental to the physical, mental, moral and social well-being of the child ${ }^{13}$. Accordingly, a work amounts to child labour if it is exploitative and/or injurious to any aspect of the developing personality of the child. In order to determine when a child is involved in child labour, the United Nations Children Emergency Fund ${ }^{14}$ (UNICEF) provided a list of indices to be considered to wit:

1) Starting full-time work at too early an age;

2) Too many hours spent on work within or outside the family leading to excessive fatigue;

3) Depriving children of their rights to education where schools are available or interfering with their education;

4) Participating in work that results in excessive physical, social and psychological strains on the child;

5) Too much responsibility for a child;

6) Low wage; and

7) Work that does not facilitate the psychological development of the child for example, dull repetitive tasks which do not stimulate a child's creative abilities etc.

However, child labour is not the same thing as "light work" done by children. Light work ${ }^{15}$ means any work that does not interfere with the child's health and development and its regular school attendance. Light work includes domestic chores such as washing of utensils, cloths, supervised training and artistic undertakings. In all these, the age of the child should be the paramount consideration.

The work aims at examining the meanings of child and child labour. It undertakes an in depth appraisal of the more aggravated forms of child labour vis-à-vis the impact of international and local legislations. It also shows the nexus between the causes and consequences of child labour. In doing this, the following research questions have been formulated:

1. Who is a child and what is child labour

2. What are the worst forms of child labour

3. What is the impact of anti child labour laws

4. What are the causes and consequences of child labour

The outline of the work is as follows: (a) abstract, (b) introduction (c) Worst forms of child labour vis-à-vis international and local legal instruments (d) Causes and consequences of child labour, and (e) Conclusion and recommendations. In discussing the research outline, the authors employed the doctrinal research methodology.

\section{Worst Forms of Child Labour Vis-À-Vis International and Local Legal Instruments}

ILO Worst Forms of Child Labour Convention itemizes them as follows:

a. All forms of slavery or practices similar to slavery, such as the sale and trafficking of children, debt bondage and serfdom and forced or compulsory labour including forced or compulsory recruitment of children for use in armed conflict;

b. The use, procuring or offering of a child for prostitution, for the production of pornography or for pornographic performances;

c. The use, procuring or offering of a child for illicit activities in particular for the production and trafficking of drugs as defined in the relevant international treaties;

d. Work which by its nature or the circumstances in which it is carried out is likely to harm the health, safety or morals of children.

This section considers the various categories of the Worst Forms of Child Labour vis a vis international and local legal regimes for combating them. The methodology to be employed in this discourse is to examine the content of each category and X-ray applicable legal instruments.

\subsection{Child Trafficking}

There is evidence that the practice of trafficking human beings has existed for thousands of years (Omozele, 2011).

\footnotetext{
${ }^{13}$ Child Labour Laws in the United States, P.2, op. cit. supra, note 1.

${ }^{14}$ The situation of working children and street children (1980)/UNICEF/CRP. p. 3.

${ }^{15}$ ILO Minimum Age Convention, article 7 (1), supra, note 9.
} 
However, it gained global attention in the $1990 \mathrm{~s}^{16}$. The spotlight fell on child trafficking in Africa particularly in West Africa in 1987 following the heavy trafficking of children from the Republic of Benin to Cameroon, Nigeria, Cote d' Ivoire and Gabon. ${ }^{17}$

Although no precise figure exists, the ILO in 2005 estimated that 980,000 to 1,225,000 children both boys and girls are in forced labour situation as a result of trafficking. In a layman's parlance, child trafficking is about taking a child out of its protective environment and prying on its vulnerability for the purpose of exploitation. ${ }^{18}$ Specifically in 2000, an internationally accepted definition of trafficking in persons was provided by the Palermo Protocol. ${ }^{19}$ The Protocol ${ }^{20}$ defines trafficking in persons as- - The recruitment, transportation, transfer, harbouring or receipt of persons, by means of the threat or use of force or other forms of coercion, of abduction, of fraud, of deception, of the abuse of power or of a position of vulnerability or of the giving or receiving of payment or benefits to achieve the consent of a person having control over another person, for the purpose of exploitation..." ${ }^{21}$ In other words, trafficking in persons under the Protocol means the recruitment of persons by fraudulent or other specified improper means for exploitative purposes. Thus, for an act to amount to trafficking in persons, three elements must be established to wit-an act (recruitment), improper means (such as fraud, force, deception) and purpose (for the purpose of exploitation). ${ }^{22}$ The Palermo Protocol in paragraph (b) of article 3 states that the consent of a victim of trafficking is immaterial provided any of the means set forth in paragraph (a) has been used.

Article 3 (c) of Palermo Protocol provides in relation to child trafficking that the recruitment, transportation, transfer, harbouring or receipt of a child for the purpose of exploitation shall be regarded as trafficking in persons though done in a manner other than the means set forth in article 3 (a). ${ }^{23}$

Articles 35 and 29 of the Convention on the Rights of a Child and the African Charter on the Rights and Welfare of the Child respectively obligate state parties to take all appropriate measures including legislation to prohibit the sale abduction and trafficking of children "Sale of Children" has been defined as "any act or transaction whereby a child is transferred by any person or group of persons to another for remuneration or any other consideration. ${ }^{24}$ It is submitted that the abduction or and sale of children for exploitative purposes amount to trafficking in person under the Palermol Protocol. Article $5^{25}$ of the Palermol Protocol enjoins state parties to criminalize trafficking in persons when committed internationally and also to punish and attempt to commit the same offence.

Under article $6^{26}$ of the Palermol Protocol, state parties are obliged to protect the privacy and identity of victims of trafficking and afford them appropriate legal aid in criminal actions against offenders. Furthermore, victims are also to be provided with measures to facilitate their physical, psychological and social recovery. In addition, they are to be provided employment, education and training where the circumstances permit. Considering that traffickers will do anything including the murder of victims in order to sabotage any legal proceeding

\footnotetext{
${ }^{16} 2006$ UN Secretary General's Study, p. 300.

${ }^{17}$ Debt Bondage: Slavery Around the World, a publication of Anti-Slavery International and Development and Peace, June, 1999 , p.5.

${ }^{18}$ UNODC on Human Trafficking and Migrant Smuggling. Available at http://www.ILO.org/ipec/areas/ trafficking of children/lang-en/index htm. Accessed on 23/10/2014.

${ }^{19}$ This is the UN Protocol to Prevent, Suppress and Punish Trafficking in Persons especially Women and Children 2000. The Protocol came into force on 25 December, 2003 and has been ratified by 163 states as at September 2014. See

http://en.wikipedia.org/wiki/protocol_to_prevent_supress_and_punish_trafficking_in_persons_specially_women_and_children. Accessed on 23/10/2014. Nigeria ratified this Protocol on 28/6/2001. Ladan, M.T. op.cit. p.24 supra, note 8.

${ }^{20}$ Palermol Protocol, article 3 (a). This definition has been adopted by article 4 (a) of the Council of Europe Convention on Action Against Trafficking in Human Beings, supra, note 8.

${ }^{21}$ Trafficking in Persons (Prohibition) Law Enforcement and Administration Act, Cap. T23, L.F.N. 2010; section 64 defines “trafficking” as "including all acts and attempted acts involved in the recruitment, transportation within or across Nigerian borders, purchases, sale, transfer, receipt or harbouring of a person, involving the use of deception, coercion or debt bondage for the purpose of placing or holding the person whether for or not in involuntary servitude (domestic, sexual or reproductive) in force or bonded labour or in slavery like conditions".

${ }^{22}$ Wikipedia, Protocol to Prevent, Suppress and Punish Trafficking in Persons especially Women and Children. Available at http://www.unodc.org/unodc/human-trafficking. Accessed on 24/10/2014.

${ }^{23}$ For a similar provision, see article 4 (c) of Council of Europe Convention on Action against Trafficking in Human Beings, supra, note 8. The Inter American Convention, supra, note 8, in article 2 (b), defines "International Traffic in Minor" as "the abduction, removal or retention, or attempted abduction, removal or retention, of a minor for unlawful purposes or by unlawful means.” For the meanings of "unlawful purpose" and "unlawful means" see article 2 (c) and (d) respectively.

${ }^{24} 1^{\text {st }}$ Optional Protocol to the Convention on the Rights of the Child on the Sale of Children Child Prostitution and Child Pornography. Adopted by the UN General Assembly Resolution A/RES/54/263 of 25 May, 2000 and entered into force on 18 January, 2002.

${ }^{25}$ See also Council of Europe Convention articles 19 and 21 and Inter-American Convention, article 7, note 8 supra.

${ }^{26}$ Ibid., articles 10, 11, 12, 13, 15 and 28 and Inter-American Convention, article 16.
} 
against them, state parties are enjoined to ensure the safety of victims while within their territories and afford them necessary support to recover compensation against their traffickers. ${ }^{27}$

Where a state party is in receipt of a trafficked person, article 7 enjoins her to grant temporary or permanent residence to the trafficked person on humanitarian ground or compassionate ground or in exchange of testimony against alleged traffickers. ${ }^{28}$ Article $8^{29}$ mandates states of origin of whom the victim of trafficking in persons is a national or has right of permanent residence to facilitate his or her own return provided that in doing this, the state of origin must inform the state in receipt of the victim of her capacity and readiness to guarantee the safety of the victim upon her return. Thus, the inability of a state of origin to ensure the safety of the victim upon return is a legitimate ground on the basis of which the country in receipt of the victim may consider activating the provisions of article 7. Facilitating the return of the trafficked person requires the state of origin to ascertain in the first place whether the victim is her national or a person with permanent right of residence and secondly to provide him or her with relevant travel documents where those are unavailable.

State parties are obligated inter alia by article $9^{30}$ to prevent the revictimization of victims of trafficking. This can be achieved by:

1) carefully distinguishing victims from traffickers;

2) Ensuring that victims are not subjected to prosecution or punishment whether in their states of origin or destination on account of 'offences' allegedly committed by them such as prostitution and immigration offences in relation to their having been trafficked.

In Nigeria, the Trafficking in Persons (Prohibition) Law, Enforcement and Administration Act ${ }^{31}$ comprehensively deals with trafficking in persons. It was enacted in 2003 and came into force on $14^{\text {th }} \mathrm{July}$, 2003. The National Agency for the Prohibition of traffic in persons is the body charged with the responsibility of ensuring compliance with the provisions of the Act. ${ }^{32}$ Section 64 defines trafficking in person in nearly the same terms as the Palermol Protocol. ${ }^{33}$ In line with article 5 of the Protocol, sections 11 - 29 of the Act provide for various offences relating to trafficking in persons.

Section 19 (1) (a) of the Act punishes the kidnap or abduction of any child to any place within or outside Nigeria with fourteen years imprisonment. Under section 21 of the same Act, ${ }^{34}$ the buying or selling of any child for immoral purpose is punishable with fourteen years imprisonment. It is important to note that the mere transaction in children does not constitute trafficking in persons.

However, where the transaction is for exploitative purpose, the offence of trafficking would have been committed. It is submitted that the phrase "immoral purpose" within the context of the Trafficking in Persons (Prohibition) Law Enforcement and Administration Act includes prostitution, rape, indecent assault and other sexual exploitations.

Another Nigerian legislation which in part prohibits trafficking in persons is the Child's Rights Act, 2003. Section 27 of this Act makes it an offence for any person to remove a child whether by abduction, kidnap or any other fraudulent means from the lawful custody of his or her parents or other care-givers. Where upon removal, the child is taken outside Nigeria with intent to return him to Nigeria; the offence is punishable with fifteen years imprisonment. Where there is no such intent, the offence is punishable with twenty years imprisonment. On the other hand, where the trafficking is within Nigeria, the offence is punishable with ten or seven years imprisonment depending on whether the removal is outside the state where the person having lawful custody of the child is resident or within the boundaries of the same state. ${ }^{35}$

Considering that trafficked persons are often confined to a particular place against their will, section 365 of the Criminal Code ${ }^{36}$ makes it an offence punishable with two years imprisonment for any person to unlawfully confine or detain a person or deny him or her, his or her personal liberty. Furthermore, intimidating or threatening a trafficked person in order to prevent him or her from disclosing the fact of his or her being trafficked is

\footnotetext{
${ }^{27}$ Palermol Protocol, article 6.

${ }^{28}$ Wikipedia, Protocol to Prevent, Suppress and Punish Trafficking in Persons, especially Women and Children, op. cit., p.3.

${ }^{29}$ See also Council of Europe Convention, article 16 and Inter-American Convention, article 11.

${ }^{30}$ Ibid., article 26.

${ }^{31}$ Trafficking in Persons (Prohibition) Law, Enforcement and Administration Act, supra, note 23.

${ }^{32}$ Section 1 of the Act establishes National Agency for the Prohibition of Traffic in Persons (NAPTIP).

${ }^{33}$ See note 23 supra.

${ }^{34}$ Section 30 of Child's Rights Act also prohibits inter alia transactions in children.

${ }^{35}$ States in this context refer to one of the component states that make up the Federal Republic of Nigeria.

${ }^{36}$ See note 5 , supra.
} 
punishable with one year imprisonment under the Criminal Code ${ }^{37}$.

\subsection{Debt Bondage and Serfdom}

Debt bondage gives rise to bonded labour. Debt bondage results from a situation where a debtor pledges his personal services or those of persons under his control as a security for debt and the reasonable value of such services is not applied towards off-setting the debt nor are the length and nature of those services limited or defined. ${ }^{38}$ Bonded labour refers to the labour of a debtor or those of persons under his control which the debtor has pledged as a security for a debt. Bonded labour "often leads to slavery by descent:..., the underlying loan often is not fully repaid before death, so the obligation to repay it is passed down to a family member. Work may be unrelenting seven days a week and without break the year round". ${ }^{39}$ Bonded labour exists because the in-built safeguards in article 1 (a) (b) of the Supplementary Convention on Slavery are not observed.

Bonded labourers are often beaten, guarded by armed personnel so as to prevent their escape and are either not paid or merely paid a pittance. It has led the Anti-Slavery International and Development and Peace to observe that bonded labourers are "non-beings, exiles of civilization living a life worse than those of animals, for the animals are at least, free to roam about as they like..." ${ }^{40}$ Trafficked persons constitute an example of bonded labourers since they are required by the traffickers to pay back a huge amount of money supposedly spent by traffickers in purchasing or transporting them within or across borders. In other words, the said sum of money is assumed by the traffickers to be a loan to the trafficked persons with the latter's labour as security.

On the other hand, serfdom has been defined as a condition in which a tenant is bound to live and labour on land belonging to the landowner and is not free to change his status. ${ }^{41}$ The practice of serfdom involves a land owner granting a piece of land to an individual known as serf and who is turn is required to render certain services such as sharing his farm produce with the land owner at harvest, working for the landowner or doing other works for example domestic chores for the landowners' household. It is important to recognize that it is not the exchange of labour in return for access to land but the inability of the serf to relinquish that status that is serfdom (Werssbrodth, 2002). This form of slavery is still practiced in countries such as India and Pakistan ${ }^{42}$ Debt bondage can result to serfdom since debt bonded labourers are either not paid or paid too little and the length of their services is not fixed. The implication of this is that the inability of the debt bonded labourers to repay the debt in their life time means that the debt can be passed down to their generations.

Section 30 (2) (b) of the Child's Rights Act prohibits practices similar to slavery such as debt bondage and selfdom. Section 369 (3) (4) and (5) of the Criminal Code criminalizes debt bondage. It provides that any person who places another in servitude for the purpose of being used as a pledge or security for debt or conveys or induces any person to come into Nigeria or leave Nigeria for the purpose of being used as a pledge or security for a debt commits an offence and is punishable with fourteen years imprisonment, without an option of fine.

\subsection{Forced Labour}

Article 2 (1) of ILO Forced Labour Convention 29 of 1930 defines "forced labour" as "all work or service, which is exacted from any person under the menace of any penalty and for which the said person has not offered himself voluntarily”. The menace can take any form such as physical violence, restraint or death threats ${ }^{43}$. An early example of forced labour was a long work of African Salves on plantations in the Western hemispheres. Modern day slavery is less obvious, people are forced to work by governments, high placed individuals or militias by threat of violence either to the "slaves" or to their loved ones. ${ }^{44}$

Trafficking in persons for exploitation is an example of forced labour. This is because trafficked persons are usually restrained and often threatened with physical violence or death threats either directed at them or to their

\footnotetext{
${ }^{37}$ Section 366 of the Criminal Code Act.

${ }^{38}$ Supplementary Convention on the Abolition of Slavery, the Slave Trade, and Institutions and Practices similar to Slavery, adopted 7 September, 1956 and entered into effect 30 April, 1957, article 1.

${ }^{39}$ Anti-Slavery International, http://en.wikipedia.org/wiki/Anti-slavery International. Accessed 21/10/2014.

${ }^{40}$ Debt Bondage: Slavery Around the World, a publication of Anti-Slavery International and Development and Peace, June, 1999 , P.4

${ }^{41}$ Supplementary Convention on the Abolition of Slavery, the Slave Trade, and Institutions and Practices similar to Slavery 1956 , article 1 (b note 17 , supra.

${ }^{42}$ Debt Bondage: Slavery Around the World, op. cit. p. 74.

${ }^{43} 2006$ UN Secretary General's Study, p.74.

${ }^{44}$ Anti-Slavery International, Supra note, 41.
} 
loved ones. It is doubtful whether trafficked persons would have willingly volunteered themselves to be trafficked if they had known the awful ordeals which await them.

Another example of forced labour is the compulsory recruitment of children for use in armed conflict. Armed conflict does not however include civil disturbances or communal conflicts. The phrase 'armed conflicts' has been defined by article 1 of Protocols 1 and 2 Additional to Geneva Conventions 1989 as embodying civil and international wars. It is submitted that where a debtor pledges the services of others as security for a debt without the latter's consent, that the labour of those individuals would have been exacted under the circumstances of forced labour.

There are several local legislations prohibiting forced or compulsory labour. The basic one is section 34 (1) (c ) of the 1999 Constitution of the Federal Republic of Nigeria (as amended) which prohibits the subjection of any one to forced or compulsory labour. Under section 73 (1) of the Labour Act, ${ }^{45}$ it is an offence punishable with a fine not exceeding N1000 or to imprisonment for a term not exceeding two years or both for anyone to require or permit another to be engaged in forced or compulsory labour contrary to section $31^{46}$ (1) (c) of the 1979 Constitution of Nigeria. However, where a public officer ${ }^{47}$ compels any group of persons to work for another without their consent, such public officer will be liable upon conviction to a fine not exceeding N200.00 or to imprisonment not exceeding six months or both. ${ }^{48}$

The use of a child for forced or exploitative labour under section 28 (1) (a) of the Child's Rights Act is an offence punishable with a fine not exceeding fifty thousand naira or to imprisonment for five years or both where the offence is committed by an individual. On the other hand, where the offence is committed by a body corporate, the proprietor, director and other officers or servants shall be deemed to be jointly and severally liable and may be liable on conviction to a fine of two hundred and fifty thousand naira. ${ }^{49}$ Section 22 (1) (a) of the Trafficking in Persons (Prohibition) Law Enforcement and Administration Act prohibits the use of any person either within or outside Nigeria for forced labour. The section imposes similar penalties as in section 28 (4) of the Child's Rights Act with the exception that where the offence is committed by an individual, he/she will be liable to a fine of $\mathrm{N} 100,000.00$

\subsection{Prostitution and Pornography}

Prostitution and pornography are instances of the Worst Forms of Child sexual abuse.

"Child sexual abuse" has been defined as the- - Involvement of dependent, developmentally immature children... in sexual activities which they do not fully comprehend and to which they are unable to give informed consent" ${ }^{30}$

Child prostitution refers to the engagement of children in sex and sex related activities for monetary compensation or any other consideration. ${ }^{51}$ This definition encompasses male and female prostitutes under the age of 18 years. ${ }^{52}$ Child Pornography on the other hand means ${ }^{53}$ -

"any representation, by whatever means, of a child engaged in real or simulated explicit sexual activities or any representation of the sexual parts of a child for primarily sexual purposes".

The import of this definition is that the representation of the sexual part of a child or a child engaged in real or simulated explicit sexual activities does not amount to child pornography if done for lawful purposes such as medical or educational purposes.

The Convention on the Right of a Child imposes an obligation on state parties to prohibit all forms of sexual

\footnotetext{
${ }^{45}$ Labour Act, note 3, supra.

${ }^{46}$ Now section 34 (1) (c ) of the 1999 Constitution (as amended).

${ }^{47}$ For the definition of Public Officer, see section 318 of the 1999 Constitution (as amended).

${ }^{48}$ Section 73 (2) of the Labour Act.

${ }^{49}$ Section 28 (4) of the Child's Rights Act.

50“"Child maltreatment” an on line publication of National Association of Counsel for Children, Colorado, U.S.A. Retrieved 5/3/2007 from: http://www/naccchildlaw .org/chidlren/law/chidlmaltreatment.html; Family Law Council, Child Sexual Abuse Report, Commonwealth of Australia, September, 1988, p.5

${ }^{51}$ Article 2 (b) of the First Optional Protocol to the Convention on the Rights of the Child on the Sale of Children, Child Prostitution and Child Pornography; adopted by the UN General Assembly Resolution A/RES/54/263 of 25 May, 2000 which entered into force on January 18, 2002. Nigeria signed this Protocol on 8/9/2000. M. T. Ladan, op. cit., note 8.

${ }^{52}$ Criminal Code Act, Cap C38, L.F.N., 2010; section 1 deals with female prostitution only.

${ }^{53}$ First Optional Protocol to the Convention on the rights of the Child; article 2 (c) roles 22 and 23 supra.
} 
abuse of children such as-

a. The inducement or coercion of a child to engage in any unlawful sexual activity;

b. The exploitative use of children in prostitution or other unlawful sexual practices;

c. The exploitative use of children in pornographic performances and materials. ${ }^{54}$

There are at least four factors which promote child prostitution and pornography. These are the trafficking of children for sexual exploitation, pedophile ${ }^{55}$, sex tourism ${ }^{56}$ and the internet. ${ }^{57}$ Section 11 of the Trafficking in Person (Prohibition) Law Enforcement and Administration Act makes it an offence for anyone to export or import any child from or into Nigeria for the purpose of prostitution. Strangely, this section did not create any sanction or punishment for the offence. According to section 36 (8) of the 1999 Constitution (as amended), for an act to amount to an offence, it must be created by a written law and the punishment thereof prescribed. In other words, section 11 has failed to create any offence. Thus, these writers are of the view that the proper section to charge any person who has allegedly exported or imported any child from or into Nigeria for prostitution is section 14 of the same.

Section 14 provides among other things that any person who procures a child for the purpose of prostitution ${ }^{58}$ in or outside Nigeria is liable on conviction to ten years imprisonment without an option of fine.

Section 26 of the above Act provides that where a person is resident in Nigeria and keeps a brothel or allows a child to be in a brothel ${ }^{59}$ or to trade in prostitution or permits the defilement of a child in his premise or procures, uses or offers any person for pornographic activities commits an offence and is liable on conviction to imprisonment for ten years. Although section 26 is headed "Offences by alien", it is submitted that where a Nigerian resident in Nigeria commits any of the offences listed therein, he can be charged under that section. But where an alien is charged and convicted under section 26, he shall be deported after serving his sentence. ${ }^{60}$

What then is a brothel? Section 64 of the Act defines brothel as including-“any enclosure, house, premises, hotels, restaurants, drinking places, vessels or stationary or moving receptacles where a person offers her body commonly for acts of lewdness and sexual gratification”. Unlike the definition of brothel under the Trafficking in Persons Act, the English Courts in interpreting section 13 (1) of the Criminal Law (Amendment) Act, 1885 which is similar to section 225B of the Criminal Code have held that a woman who occupied a house and admitted men frequently for sexual gratification was not guilty of keeping a brothel. ${ }^{61}$

Section 223 of the Criminal Code prohibits the procurement of a girl or a 'woman' under 18 years with the intent that she should become a common prostitute or an inmate of a brothel whether in Nigeria or elsewhere. Similarly, section 30 (2) (e) of the Child's Rights Act criminalizes the procurement of a child for prostitution, pornography or pornographic performances. Both sections do not create any "offence" ${ }^{\text {"62 }}$ It is arguable that where a child or person protected by the aforementioned sections have been carnally known, the procurer and the person who has taken carnal advantage of the child or person can be charged under section 31 (1) (2) (3) of the Child's Right Act as accomplices. ${ }^{63}$

\footnotetext{
${ }^{54}$ Convention on the Rights of the Child, article 34, note 8, supra. See also the African Charter on the Rights and Welfare of the Child article 27 (1) (c) note 8, supra.

${ }^{55}$ Literally, pedophile means "Love of Children.” However, it is used derogatively to refer to the sexual pervasion of adults who are desirous of sexual relationship with children. Such adults are referred to as pedophilia. J. Foreman "Can We End the Shame? Recent Multilateral Efforts to Address the World Child Pornography Market” in V. and. J. Transact, L.L (1990), Vol. 23, No. 2, P. 437.

${ }^{56}$ Sex tourism means traveling to a foreign country with the primary purpose of engaging in sexual activities. Where those engaged in such sexual activities are children, this is termed "child sex tourism or sex Tourism of children". What is sex Tourism of Children? Retrieved 6/22/2007 from: http://www.missingkids.org/missingkids/servlet/PubCaseSearchServlet?act=usMapSearch\&missState=CT

${ }^{57}$ The internet has aggravated the problem of child pornography by inter alia: (a) it allows access to a vast quantity of pornographic images from around the world, (b) it facilitates the sharing of pornographic images among users; R. Wortlay and S. Smallbone, "Child Pornography on the Internet”, U. S. Department of Justice, Problem—Oriented Guides for police Problem—Specific Guides Series, No. 41. Retrieved 6/22/2007 from www.hps.usdoj.gov., p. 8

${ }^{58}$ Under section 13, it is an offence punishable with ten years imprisonment for any person to cause a child to engage in prostitution while section 15 punishes the procurement of a child for prostitution with 14 years imprisonment without an option of fine.

${ }^{59}$ Section 225B of the Criminal Code makes it an offence for any person to keep, manage or assist in the management of a brothel.

${ }^{60}$ Unless the provisions of the Transfer of Convicted Offenders (Enactment and Enforcement) Act, Cap T16 LFN 2010 apply.

${ }^{61}$ Singleton v Ellison (1895) 1 QB 607 and Caldwell v. Leach (1913) 109 L.J 188 at 190. In Donovan v Gawin (1956) 1! B 67, the Court held that for a premise or a room to constitute a brothel, it must harbour more than a prostitute and where the prostitute occupies a set of rooms or parts of a premises, the premise becomes a brothel if the rooms "are sufficiently close to each other to constitute in effect what might be called a nest of prostitutes."

${ }^{62}$ See our discussion of section II of the Trafficking in Person (Prohibition) Law, Enforcement and Administrative Act, note 23 supra.

${ }^{63}$ See the definition of parties to offences under section 7 of the Criminal Code.
} 
Section 31 (1-3) of the Child's Rights Act creates a strict liability offence. It provides that any one who has carnal knowledge of a child commits the offence of rape ${ }^{64}$ punishable with life imprisonment. It is immaterial that the child consented to it or that the offender believed that the child was up to 18 years of age.

Under section 18 of the Immigration Act any alien resident in Nigeria or who seeks to be admitted into Nigeria but is a prostitute, a brothel keeper, a householder who allows the defilement of a young girl in his premises, a person who permits a child under 13 years to be in brothel or encourages the prostitution of such a child or a person trading in a prostitution may be deemed to be a prohibited immigrant and may be refused entry into or deported from Nigeria.

\subsection{Illicit Activity and Drug Trafficking}

Drug trafficking is a global phenomenon. It is one of the most serious offences. Narcotic drug means ${ }^{65}$ any of the substances natural or synthetic, in schedules 1 and II of the Single Convention on Narcotic Drug 1961 as amended by 1972 Protocol. On the other hand, psychotropic substance means any substance natural or synthetic or any natural material in schedules 1, II and III of the Convention on Psychotropic Substances, $1971 .^{66}$

The UN Convention against Illicit Traffic in Narcotic Drugs and Psychotropic Substances defines illicit traffic in article 3 paragraphs (1) and (2) to mean inter alia the intentional

"Production, manufacture, extraction, preparation, offering, offering for sale, distribution, sale, delivery on any terms whatsoever... transport, importation or exportation of any narcotic drug or any psychotropic substance contrary to the provisions of the 1961 Convention as amended or the 1971 Convention”,67

There is a correlation between the engagement of children in drug trafficking, substance abuse and crime. ${ }^{68}$ Children who are used in the illicit traffic of drugs gradually become addicted to those drugs. Often, they engage in criminal activities to secure the financial capacity with which to buy the drugs and fuel their addictions. Children also engage in drug trafficking to earn a livelihood.

Research has shown that the use of drugs exacts a significant toll on human lives and productive years. In 2012, over 183,000 drug related deaths were recorded. Globally "it is estimated that in 2012, between 162 million and 324 million people, corresponding to between 3.5 percent and 7.0 percent of the world population aged 15 - 64, had used an illicit drug-mainly a substance belonging to the cannabis, opiord, cocaine or amphetaminetype stimulants group-at least once in the previous years"

Worldwide, about $12.7 \mathrm{~m}$ people use drugs via injection. The sharing of used injecting equipments exposes the victims to the risk of contracting HIV and hepatitis C. It is estimated that an average of 13.1 percent of the total number of people who inject drugs are living with $\mathrm{HIV}^{70}$

In Nigeria, the National Drug Law Enforcement Agency Act is the basic instrument for dealing with illicit use and trafficking of drugs. The Act came into effect on $25^{\text {th }}$ December, 1986. Section 1 of the Act establishes the National Drug Law Enforcement Agency for the purpose of combating the cultivation, processing, sale, trafficking and use of hard drugs. It also empowers the Agency to investigate persons suspected to have dealings in drugs and other related matters.

The Act defines narcotic drugs in tam dem with the definition in Single Convention of Narcotic Drugs 1961

\footnotetext{
${ }^{64}$ Section 357 of the Criminal Code Act provides for the offence of rape. It provides that anyone who has unlawful carnal knowledge of a woman or girl without her consent or where the consent was obtained by force or fraudulent means is punishable with life imprisonment with or without caning. With the enactment of section 31 (1) - (3) of the Childs' Rights Act, It is suggested that the offence of rape in respect of the girl-child should no longer be charged under section 357 of the Criminal Code since the former provision offers better protection to the girl-child than the latter. See also sections 282 and 283 of the Panel Code in respect of the offence of rape and the punishment thereof respectively.

${ }^{65}$ Article 1 (1) (J) of the Single Convention on Narcotic Drugs 1961 and article 1 (n), United Nations Convention Against Illicit Traffic in Narcotic Drugs and Psychotropic Substances, 1988.

${ }^{66}$ Article 1(r) of the Convention on Psychotropic Substances, 1971.

${ }^{67}$ For other definitions of illicit traffic, see article $1(\mathrm{~m})$ of the Convention Against Illicit Traffic on Narcotic Drugs and Psychotropic Substances, 1988; article 1 (1) (i) of the Single Convention on Narcotic Drugs 1961 and article 1 (g) of the Convention on Psychotropic Substances, 1971.

${ }^{68}$ The UN Secretary General's Study on the Impact of Violence against Children

${ }^{69}$ United Nations Office on Drugs and Crime, World Drug Report, 2014, p. 11. Accessed on 13/11/2014 https://www.unodc.org/documents/wdr2014/World_Drug_Report_2014_web.pdf

${ }^{70} \mathrm{Ibid}$.
} 
as amended by the 1972 Protocol. ${ }^{71}$ On the other hand, psychotropic substances was defined in the same terms as in schedules 1, II, III and IV of the Convention on Psychotropic Substances $1971 .^{72}$

Nigeria does not have a yearly statistics on the involvement of children in drug trafficking and its impact on them. However, the 1999 situation assessment of drug abuse in Nigeria, found that cannabis, being the only drug produced in large scale in the country, in the drug most widely peddled by children. Furthermore, the study found that 8.2 percent of children, aged 10 - 19, have used cannabis sometimes in their lives. Most of these children had been engaged in trafficking the drugs. ${ }^{73}$

\subsection{Works Likely to Harm the Health, Safety and Morals of Children}

Article 4 (1) of the ILO Convention 182 provides that in determining works which are likely to harm the health, safety and morals of children, recourse should be had to national laws or regulations or to the competent authority after consultation with the organizations of employers and workers concerned. Account should be taken of relevant international standards particularly paragraphs 3 and 4 of the Worst Forms of Child Labour Recommendation 1999. Paragraph $3^{74}$ contains the following indices which should guide state parties in identifying works likely to harm the health, safety and morals of children:

a) Work which exposes children to physical, psychological or sexual abuse;

b) Work underground, under water, at dangerous height or in confined spaces;

c) Work with dangerous machinery, equipment and tools or which involve the manual handling or transport of heavy load;

d) Work in an unhealthy environment which mainly for example expose children to hazardous substances, agents or processes or to temperature, noise levels or vibrations damaging to their health;

e) Work under particularly difficult conditions such as work for long hours or during the night or work where the child is unreasonably confined to the premises of the employer.

There is no specific Nigerian legislation or regulation that has categorized those works which by their nature or circumstances under which they are performed are likely to harm the health, safety and morals of children. However, the engagement of children in begging ${ }^{75}$, hawking, factory work, domestic labour ${ }^{76}$, scavenging, brothel, bus conducting, iron and metal work and farm and quarry work ${ }^{77}$ fall within the ambit of paragraph 3 of Recommendation 190.

The Child's Rights Act prohibits the use of a child for the purposes of begging for alms, guiding beggars, prostitution, domestic or sexual labour ${ }^{78}$; as a slave, or for practices similar to slavery, trafficking of the child,

\footnotetext{
${ }^{71}$ The Act in defining Narcotic drugs made reference to the Convention on Narcotic Drugs and Psychotropic Substances, 1988.

${ }^{72}$ National Drug Law Enforcement Agency Act, Cap. N30, L.F.N. 2010, section 52.

${ }^{73}$ Children and Women's Rights in Nigeria: A Wake-up-call, op. cit., p. 224.

${ }^{74}$ ILO Worst Forms of Child Labour, Recommendation No 190 of 1999 (hereinafter referred to as "Recommendation 190"). Other examples of works likely to be injurious to the health, safety and morals of children can be found in article 5 (3) of the ILO Minimum Age Convention 1973, No 138.

${ }^{75}$ In both Northern and Southern parts of Nigeria, Children can readily be found begging for alms both in public and private places. Those who beg for alms in traffics can easily be crushed by vehicles while those who beg from house to house may be abducted by traffickers or be sexually abused. One class of beggars found in the Northern part of Nigeria which should be mentioned are the Almajiria. These are koranic pupils entrusted to teachers otherwise known as mallams. Since these koramic teachers take more pupils than they can cater for, their pupils are sent out to beg for alms. The Rights of the Child in Nigeria (Ayua, A. and Okegbue, I. eds.) Lagos, Nigerian Institute of Advanced Legal Studies, 1996, p. 176. On account of the high number of Amajiris roaming Northern part of Nigeria begging, the Federal Government recently established several model Amajiri schools to provide western and koranic education.

${ }^{76}$ Unlike what was obtainable in Nigeria, where child domestic servants worked in the homes of relatives who treated them as their own children, today child domestic servants work beyond their extended families and are paid cash in exchange for services rendered. These children are procured by middlemen largely from impoverished households and placed in families that pay the middlemen the agreed wage and the later in turn pays a stipend to the child domestic servant. Most of these children are sexually abused, harshly punished and denied education: Children's and Women's Rights in Nigeria: A-Wake-up-Call, Abuja: National Planning Commission, and UNICEF, Nigeria, PP: 206-207; Ladan, M. T., “The Rights of Child Domestics as Victims of Human Rights Violation and Trafficking in Nigeria," a paper presented at a Workshop for Judges, Magistrates and Prosecutors from 21-22 September, 2005 at Country-Home Hotel, Jos, Plateau State, pp. 5-6. Retrieved on 5/10/2007. Available at http://www.dawodu.com/Ladan3.htm.

${ }^{77}$ Agriculture employs the highest number of child Labourers worldwide. ILO in 2005 estimates that $60 \%$ of Children are engaged in agricultural work. Children hired as agricultural workers work for long hours and are exposed to hazardous. Substances such as pesticides and are often sexually abused; Human Rights Watch” Backgrounder: Child Labour in Agriculture http://hrw.org/backgrounder/crp/back0610.htm pp. 1-8. Retrieved on 5/3/2007.
}

${ }^{78}$ Section 30 (2) (a) of the Child's Rights Act. 
debt bondage or serfdom and forced or compulsory labour. ${ }^{79}$

Furthermore, the Act forbids the use of children for hawking of goods or services on main city, streets, brothels or high ways ${ }^{80}$ or for pornography ${ }^{81}$ and any activity in the production or trafficking of illegal drugs ${ }^{82}$. Unfortunately, the above provisions do not create any offence since they do not provide for sanctions ${ }^{83}$ in the event of breach.

Section 28 (1) (c) of the Child's Rights Act makes it an offence for anyone to cause a child to lift, carry or move anything as to be detrimental to his or her health. Again, no child shall be employed as a domestic help outside his own home or family environment ${ }^{84}$ or in any industrial undertaking. ${ }^{85}$ Anyone who contravenes subsections 1 and 2 of section 28 of the above Act is liable on conviction to a fine of fifty thousand naira or imprisonment for a term of five years or both. ${ }^{86}$

\section{Causes and Consequences of Child Labour}

There is a variety of causes of child labour particularly the Worst Forms of Child Labour. This is also true of its consequences. This section discusses first the causes of child labour and thereafter its consequences.

\section{Causes of Child Labour}

\subsection{Poverty}

Poverty is undoubtedly the predominant cause of child labour around the world. Children of impoverished households and parents who have no means of subsistence are most likely to engage in child labour in order to survive $^{87}$. Although in Nigeria, the National Minimum Wage is N18000.00 per month, some of the component states have refused to implement the Act on ground of alleged paucity of fund. Considering the staggering rate of unemployment in Nigeria, so many parents rather than risk loosing their jobs, prefer to be paid a pittance.

\subsection{Lack of Education}

Another primary cause which drives child labour is the absence of schools or qualitative education. According to $\mathrm{ILO}^{88}$, Children work because they do not have any better alternative. It has been observed that in many communities particularly the rural areas ${ }^{89}$ -

"Where between $60 \%$ - 70\% of child labour is prevalent, do not posses adequate school facilities. Even when schools are sometimes available, they are too far away, difficult to reach, unaffordable or the quality of education is so poor that parents wonder if going to school is really worth it”. One other critical causes of child labour is lack of educational resources, such as chairs, desks, insufficient teachers or poorly qualified teachers. Sometimes, the parents of children engaged in child labour are either not educated or well educated so they do not see the importance of sending their children to school.

\subsection{Harmful Cultural Practices}

In Africa and other developing countries, certain cultural practices have rationalized child labour. Some uninformed populace view "child labour" as a way of building the character and equipping with necessary skills to face future challenges. In many cultures inclusive of Nigeria, many believe that the girl child education is a bad

\footnotetext{
${ }^{79}$ Ibid., section 30 (2) (b).

${ }^{80}$ Ibid., section 30 (2) (c).

${ }^{81}$ Ibid., section 30 (2) (e).

${ }^{82}$ Ibid., section 30 (2) (f).

${ }^{83}$ Section 36 (8) of the 1999 Constitution of Nigeria (as amended).

${ }^{84}$ Section 28 (1) (d) of the Child's Rights Act.

${ }^{85}$ Ibid., section 28 (2).

${ }^{86}$ Ibid., section 28 (3).

${ }^{87}$ International Labour Office, Report of the Director-General, Child Labour, Int'l Lab. Conf., 69 ${ }^{\text {th }}$ Session, (1983) P. 11; Child Labour Laws in the United States, available on line at https://en.wikipedia.org/wiki/Child_labor laws in the United States. Accessed on 23/10/2014; Onyegbule "Way out-of Child Labour” Vanguard, Monday, November 12, 2001, p.39.

88“Child Labour Causes” ILO, United Nations, 2008 cited in “Child Labour Laws in the United States” p. 5.

${ }^{89}$ “Child Labour Laws in the United States” Op. Cit., p.5.
} 
investment. Thus, such girls are pushed into the street to trade while some others end up as domestic servants. ${ }^{90}$

\subsection{Lack of Family Planning}

The importance of family planning is to enable parents to give birth to the number of children they can adequately cater for. However, where uninformed parents fail to take advantage of available family planning methods, the consequence generally is an over blotted family size well beyond the means of such parents. There is no doubt that a relationship exists between a large family size and the incidence of child labour. Thus, Flekhoy has argued that the procreation of children for whose care sufficient resources are not available and whose existence threatens the health of those already born is a fundamental cause of child abuse.

\subsection{Loss of Parents}

The global on-slot of HIV/AIDs has orphaned many a child. According to UNAIDS, 2,200,000 children in Nigeria have lost either one or both parents to HIV/AIDs. ${ }^{91}$ In addition, many children have lost their parents through accidents, ill health and other sundry causes. With the loss of their bread winners, these children are left to fend for themselves. This invariably contributes to the incidence of child labour and street children which definitely promotes child labour.

\subsection{Broken Homes}

The divorce of couples and remarriage by one of them often traumatizes children from broken homes. Such children are, in most cases maltreated and neglected by their step father or mother. A case in point was reported in Vanguard News paper. ${ }^{92}$ It involved a 12 year old boy who ran away from home on the account of the neglect he suffered following the remarriage of his mother.

\section{Consequences}

\subsection{Injuries, Disabilities and Deaths}

Children who are hired as agricultural workers frequently suffer cuts from sharp knives and other objects and run the risk of back injuries from hauling heavy loads of produce. These children often work in freshly sprayed field and sometimes work while pesticides are being sprayed. Consequently, some of them suffer headache, fever, dizziness, nausea, rashes, diarrhea etc and sometimes death ${ }^{93}$.

\subsection{Sexual Consequences}

Children who have been sexually abused suffer severe adjustment problems such as depression, low self esteem, mistrust of adults, anger and hostility. Younger children might, in addition, have sleep difficulty, loss of appetite, fear and anxiety. ${ }^{94}$

A sexually abused child may become infected with sexually transmitted diseases, including HIV. She may become pregnant, which in turn may lead to child abandonment, abortion or complications associated with childbirth by under-aged children. ${ }^{95}$

\subsection{Perpetuation of Poverty}

There is no doubt that children engaged in certain types of child labour such as hawking, agricultural work and bus conducting contribute financially to their families. It is noteworthy however that child labour can also ruin a family's purse and push the family deeper into poverty if the child labourer sustains serious injuries (Flekhoy, 1992).

\footnotetext{
90 "Status of the girl-child in Nigeria and the Child’s Rights Act, 2003”, p. 108.

${ }^{91}$ UNAIDS, Report on the Global Aids Epidemic, 2013 www.kff.org/global-indicator/aids-orphans/retrieved on 23/11/2013.

${ }^{92} 2^{\text {nd }}$ April, 1994, p. 4.

${ }^{93}$ Human Rights Watch, Backgrounder: Child Labour in Agriculture; P. 1, http://hrw.org/backgrounder/crp/back0610.htm. Retrieved on 05/03/2007.

${ }^{94}$ L. E. Bark, Child Development, Massachusetts, Pearson Education Company, 2000, p. 590; 2006 UN Secretary General’s Study, p.15.

${ }^{95}$ Children's and Women's Rights in Nigeria: A-Wake-up-call, Op. Cit. p. 201.
} 
Child labour may also interfere with a child's education and consequently restrict his future earning capacity. This can also impoverish a country, depending on the number of her children whose education is affected, by restricting its economic advancement (Glut, 1995).

\subsection{Street Children and Crime}

Children who have suffered sexual abuse or extreme neglect ${ }^{96}$ in their homes may run away from home and drift into street life. In other words, they live, sleep and work on the street. Street children are often drawn into crime, in order to survive. The African Guardian, writing on street kids' narrated a story of a boy of 10 who on account of hunger drifted into street life. Once there, he started picking pockets and gradually became more ruthless and learnt the use to which he could put a pen knife and gun. ${ }^{97}$ Unfortunately, there is no statistics on the number of street children in Nigeria nor the percentage engaged in crime (Ngboawaji, Eke, \& Igbanibo, n.d.).

\subsection{Other Consequences}

Child labour may, sometimes result in medical cost for the treatment, rehabilitation and reintegration of the victim into the society. Where the victim turns to drug and crime, legal cost may be incurred by the parents or the state to secure his legal representation and, ultimately, if he is institutionalized, the state incurs further expenses in the running of the institution and his up-keep.

Child labour may also lead to exhaustion and malnutrition. Child labourers often work 16 hours a day. ${ }^{98}$ Some of these child workers perform heavy manual labour and yet do not earn enough to feed themselves adequately. ${ }^{99}$ It is important to recognize that child labour generally constitute a violation of human rights of those children. Their rights to life, freedoms of expression, association and movement and rights to dignity and privacy are often abused.

\section{Conclusion and Recommendations}

This work has considered child labour especially the more aggravated forms of child labour from the perspectives of international and local legislations dealing with the same. It has also examined the causes and consequences of child labour. It is therefore recommended that the law enforcement agents particularly the police, the immigration, and in Nigeria, the Nigerian Security and Civil Defence Corps should be trained and retrained on the methods and means adopted by traffickers, the prosecution of accused persons and the protection of victims of trafficking in persons. The training should also enhance the capacity of law enforcement agents to be able to distinguish between traffickers and victims in order to ensure the protection of the latter. Law enforcement agents should also be ready to corporate with each other and to exchange and share information in order to enhance their effectiveness. ${ }^{100}$

To drastically curtail trafficking in persons, states should provide law enforcement agents especially the police, the immigration and custom officers with adequate facilities such as vehicles, electronic gadgets so as to effectively police their borders. This will enable security operatives to prevent and detect trafficking in persons. In addition, the owners of commercial carriers and their operators should be obligated to ensure that passengers possess requisite travel documents for entry into the receiving state. There should also be severe sanctions for violation of this obligation ${ }^{101}$.

Furthermore, the prevention of trafficking in persons requires states to enhance the security features in travel or identity documents issued by them so as to prevent their falsification, unlawful alteration and issuance ${ }^{102}$. Moreover, states should by legislation ensure that traffickers declare their assets during investigation and that proceeds and properties acquired as a result of trafficking in persons are forfeited to the state. Additionally, proceeds and properties not disclosed by traffickers should be forfeited upon discovery ${ }^{103}$.

\footnotetext{
${ }^{96} 2006$ UN Secretary General's Study, p. 69.

${ }^{97}$ African Guardian Magazine, September 1, 1988, pp. 8-10.

${ }^{98}$ Human Rights Watch, Backgrounder, note 97, supra.

${ }^{99}$ Causes of Child Labour, ILO/IPEC, http://www.tnchildlabour.tn.gov.in/consequences.htm. Accessed on 23/10/2014.

${ }^{100}$ See the Palermol Protocol, article 10, note 8, supra, and Council of Europe Convention, article 10 (1), note 8, supra.

${ }^{101}$ The Palermol Protocol, article II and Council of Europe Convention, article 7.

${ }^{102}$ The Palermol Protocol, article 12 and Council of Europe Convention, article 8.

${ }^{103}$ Trafficking in Persons (Prohibition) Law, Enforcement and Administration Act, sections 35 and 36.
} 
It is also suggested that states should establish victims of Trafficking Trust Fund ${ }^{104}$ into which proceeds and money realized from the sale of property confiscated from traffickers should be paid. States should also provide an annual budget which should be paid into the victims of Trafficking Trust Fund.

Some other measure which would deter the trafficking in persons is to revoke the passports or visas ${ }^{105}$ of persons who have been convicted in relation to any offence pertaining to trafficking in persons, and the provision of free compulsory and readily accessible primary and secondary education. The reasons appear obvious. First, the longer children are kept in school, the longer they are restrained from joining the workforce. Second, education will help them to secure more rewarding jobs in the future and thus protect their own children from child labour.

Also, the reduction of unemployment and the payment of meaningful wages or salaries will cut down the population of a state living below poverty line. Furthermore, the payment of unemployment benefits to the unemployed adults will help keep their children from child labour.

With respect to local legislations, it is suggested that where two legislations provide for the same offence, the trafficker should be charged under the law with severer sanction ${ }^{106}$. It is also recommended that statutory provisions intended to criminalize a specific subject matter but which nonetheless did not provide for sanctions should either be deleted or requisite sanctions be provided ${ }^{107}$. On the whole, states should by legislation severely punish forced labour, the use of children in armed conflict, child prostitution and pornography, child bonded labour and serfdom. Similarly, the government, Non-Governmental Organizations, religious bodies, the media and educational institutions should enlighten the populace on the dangers of child labour mostly the Worst Forms of it.

\section{References}

Glut. T. A. (1995). Changing the Approach to Ending Child Labour: An International Solution to an International Problem. Vandlerbilt Journal of Transnational Law, 28, 1207-1208.

Flekhoy, M. G. (1992). Attitudes to Children-Their Consequences for work for Children. In: M. Freeman \& P. Veerman, Eds., The Ideologies of Children's Rights (p. 206). London: Martinus Nijhoff Publishers.

Omozele, E. M. (2011). Human Trafficking in Nigeria: An Appraisal of Legal Instruments for Combating the Crime. The Nigerian Law Journal, 15, 25.

Werssbrodth, D. (2002). Anti-Slavery International Abolishing Slavery and Its Contemporary Forms. United Nations, New York, p. 11.

Ngboawaji, D. N., Eke, P., \& Igbanibo, S. T. (n.d). Street Children and the Challenges of National Security: Evidence from Nigeria.

http://bangladeshsociology.org/Street\%20Children\%20and\%20the\%20Challenges\%20of\%20National\%20security.pdf

\footnotetext{
${ }^{104}$ Ibid., section 35.

${ }^{105}$ The Palermol Protocol, article 11 (5), Council of Europe Convention, article 7 (5), and Trafficking in Persons (Prohibition) Law, Enforcement and Administration Act, section 34.

${ }^{106}$ Compare the Child's Rights Act, section 27 (1) (2) (a) (i) (ii) with Trafficking in Persons (Prohibition) Law, Enforcement and Administration Act, section 19 (1) (a).

${ }^{107}$ Child's Rights Act, sections 28 (1) (a), 30 (2) (b) (e), Criminal Code Act, section 223 and Trafficking in Persons (Prohibition) Law, Enforcement and Administration Act, sections 11 and 22 (1) (a).
} 